\title{
Corporate Governance a Tool for Curbing Earnings Management Practices in Nigeria: Preparers Perspective
}

\author{
Obigbemi Imoleayo Foyeke \\ Department of Accounting, Covenant University, Ota, Ogun State, Nigeria \\ imole.obigbemi@covenantuniversity.edu.ng \\ Omolehinwa Eddy Olajide \\ Departmenet of Accounting, University of Lagos, Akoka, Lagos, Nigeria \\ eomolehinwa@unilag.edu.ng \\ Mukoro Dick Oluku \\ Department of Accounting, Covenant University, Ota, Ogun State, Nigeria \\ oluku.mukoro@covenantuniversity.edu.ng \\ Obamiro John Kolade \\ Department of Business, Lagos State University, Ojo, Lagos, Nigeria \\ obamirojohn
}

Doi:10.5901/mjss.2016.v7n2p234

\begin{abstract}
Corporate governance, an end to a means and a means to an end has been said to be a major tool for ensuring transparency and accountability in the business environment. Adopting the stakeholders theory, we examine the role of corporate governance in restraining earnings management practices in Nigeria as perceived by the preparers of the report. The study employed the use of primary data gathered from the research questionnaire administered to 354 sampled preparers of financial reports in Nigeria. The Pearson Correlation Coefficient and the Ordinary Least Square (OLS) regression was used to evaluate the relationship between earnings management and corporate governance attributes as identified by the study. The preparers of financial reports in Nigeria admitted that with effective corporate governance mechanisms in place, earnings management practices will reduce to the bearest minimum in the country. This study therefore concludes that earnings management practices can be deterred with effective corporate governance practices in place. It is therefore recommended that regulators at all levels should ensure strict adherence to the contents of the code of corporate governance as published.
\end{abstract}

Keywords: Earnings Management, Board Structure, Audit Committee Structure, Corporate Governance

\section{Introduction}

The relevance of accounting is premised on its ability to provide relevant financial and non-financial information to the various stakeholders; the information provided however, depends on the type of relationship that exists between the company and its stakeholders. Accounting, which is also referred to as the language of business, informs the various stakeholders of a business the review of all activities that emerged within the business entity during the reporting period in a quantitative manner (Amernic \& Craig, 2009; Chih-Fong \& Yen-Jiun, 2009). It can also be referred to as the medium of communication within and outside a business enterprise. It is a means through which the managers of the business relate with the owners of the business and other stakeholders in the business serving as a means through which stewardship and accountability is reported (Amernic \& Craig, 2009). Accounting information, however is expected to fulfil the purpose of minimizing uncertainty about the state of affairs in the reporting entity (Akintoye, 2009).

The stakeholders of any business enterprise are also referred to as the users of the financial reports of the business enterprise (Murya, 2010; Appalachian, 2006; Freeman, Wicks, \& Parmar, 2004; Universal College of Accountancy, 2004). These stakeholders use the contents (financial data) of these reports for economic decision-making 
(Murya, 2010; Chih-Fong \& Yen-Jiun, 2009). They can categorised into internal and external users (Koornhof, 1998). The internal users are those who make decisions directly affecting the internal operations of an enterprise, while the external users are those who use the financial and non financial information of a business enterprise to make decisions concerning their relationship with the enterprise on whether to continue, withdraw or improve on their present level of business relationship (Universal College of Accountancy, 2004; Koornhof, 1998). Both groups benefit by receiving the needed information to make economic decision (Sori, 2009; Chih-Fong \& Yen-Jiun, 2009).

However, the capability of these reports to meet the needs of the users is what informs the usefulness of the report, and the level of reliability placed on it by the users of the report, however, when a financial report does not meet the needs of its users, it becomes of low value (Uadiale, 2012; Accounting Aisle, 2011; Kothari; Karthik \& Skinner, 2010; Stanford, 2005; Hand, 2004). The value of financial data is a function of the quality of report presented, which is also dependent on the rate at which the users rely on the information given for decision making (Kothari et al., 2010). If the content of the financial data is faulty, it gives a wrong picture of the business enterprise, which also affects the level of reliance placed on it by the users and finally faulting the credibility of the financial report (Uadiale, 2012). The reliability of accounting information by the users of the information affects the value of the firm reporting (Otusanya \& Lauwo, 2010).

\section{Review of Literature}

\subsection{Financial Reporting in Nigeria}

The effectiveness and value relevance of any financial statements therefore is dependent on the ability of the report to meet the information needs of the various users (Revsine, 1969). However, due to the numerous users and their divergent interest in the company, the manager is faced with the challenge of reporting to meet the information needs of all. The external users of accounting information are creditors, investors, financial analysts, government, general public etc, while on the list of the primary users of the financial reports are the shareholders, employees and the managers, who have divergent interests (Ireland, 2005). The users of the financial reports all deduce various information from the reports that should satisfy the needs of all the users, thus the managers are faced with the challenge of how the reports should be prepared, which is because of the divergent interests of the various users. In an attempt to meet the divergent needs of the users, the Generally Accepted Accounting Principles (GAAP), alongside other regulatory documents such as the Companies and Allied Matters Act (1990) as amended, The National Accounting Standards (now Financial Reporting Act (2011) Bank and other Financial Institution Act (for financial institutions), etc that serve as guidelines for the preparation of financial reports were adopted in Nigeria.

\subsection{Corporate Governance and Earnings Management Practices in Nigeria}

In the preparation of the reports, the managers of companies, who serve as the agents of the other stakeholders, may prepare the reports in a way that best suit them, and their decision making process, which may not necessarily be to the advantage of the other stakeholders. For example a manager in a bid to boost production of the next season may decide to increase the company's retained earnings at the detriment of the ordinary stock shareholder who is interested in receiving high dividend at the end of the period, while the manager may also decide to go for bank loan, which may also affect the collateral base of the debenture holder. The managers, because of their privileged position may exercise high control over the management of the company, the allocation of financial and non-financial resources on behalf of shareholders as well as the control of information to be disclosed to capital providers. Self-centered motives, such as the reduction in the cost of research and development to increase book profit as well as the use of other creative accounting measures, to boost bonus, and commission, tempts managers to divert company's resources to activities that may detrimental to the objective of maximizing shareholders' wealth (Ramly \& Rashid, 2010). This act is as a result of the use of the GAAP, that requires the use of judgment, or discretion on the part of the manager (accountant), in the preparation of the financial reports (Bello, 2011; Joseph \& Atul, 2007). The exercise of accounting discretion when making financial decisions allow managers the leverage to manage earnings by moving revenue or expense items of one accounting period to another accounting period. When this happens, it reduces the total expenses for the reporting year, thereby increasing profit, also when revenue is anticipated in a future date it may be recorded in the current year thereby increasing profit. When there is also a sign of loss in a future date, current year revenue may be delayed and recorded in a future date. These acts and many more can therefore be referred to as earnings management. In the case of enron, which is a typical example of corporate failure, it was identified that the fall was as a result of the board of directors and management failure to take responsibility for the risks inherent in the company's business plan, and the use of the special 
purpose entities and related forms of structured finance, thus a misuse of off balance sheet financing as well as conflict of interest which led to the enrichment of some officers of the company (Deakin \& Suzanne, 2004).

Earnings management therefore, can be referred to as an act of maximizing the loopholes in the financial reporting laws, to maximize personal, group or organisational objectives at the detriment of other groups or individuals who may be directly or indirectly affected by such decisions. Earnings Management, can take the form of creative accounting such as recording anticipated sales in the books as turnover for the present year, as well as the reduction in the cost of research and development and any such activity that alters the true and fair nature of the presented financial reports. Earnings management could also involve the use of discretionary accruals, the accumulation of accrued expenses in the bid to give a different picture of the financial well being of the company. It is the use of deceitful actions by the preparers of the financial reports which may be at the detriment of the other stakeholders, which is the deviation of management from shareholders' interest (Murya, 2010). Management's deviation from shareholders' interests can also be as a result of the use of accounting accruals by management for personal purpose (Murya, 2010; Beaudoin, 2008; Bugshan, 2005). The use of accruals by management may be such techniques such as altering (i.e. either delaying or accelerating) actual cash flow expenditures such as advertising as well as the deferrement of research and development cost (When advertising and research and development expenditures are delayed, this will however reduce the total expenditure for the year, thus increasing profit on the short run, but will affect the business profit on the long run). This type of earnings management is called the opportunistic earnings management, whereby the manager seeks to mislead investors by pursuing his personal interest of increasing incentives such as bonus and commission, which may be a function of reported profit at the detriment of the other stakeholders, who are interested in the survival and long term profitability of the company (Liming, Charlotte, \& Shannon, 2005).

Corporate governance has received a lot of attention in the nation, and has been seen as a tool to mitigate fraudulent practices in the business environment and solution to governance challenges in Nigeria. This was birthed as a result of the enactment of the code of corporate governance in 2003 and its ammendment in 2010, with the expectation that adherence to the contents of the code by Nigerian companies will increase the level of confidence in the economy (Adegbite, 2012), as a result of the increase in confidence placed on the financial reports of companies operating in the country, which thereafter translates into increase in the rate of investment in the economy (Samaha, Dahawy, Hussainey \& Stapleton, 2012). Therefore the need to identify the various factors that may influence earnings management practices in Nigeria with regards to the role of corporate governance in its reduction.

Several studies have looked into the area of corporate governance and performance, the effectiveness of corporate governance in enhancing organisational efficiency, as well as the test of its effectiveness in curbing fraud in developed countries of the world, but few in developing countries like Nigeria. Furthermore, examination of the relationship that exists between earnings management and corporate governance as well as the test of the effect of corporate governance on earnings management has received little or no attention in Nigeria. This study therefore attempts to study the effectiveness of corporate governance in curbing earnings management practices in Nigerian companies.

The failures and distress in the business world has led to an outcry for a solution and remedy for future occurrence. This distress affected most capital markets, as the share price index of these capital markets increased in the year 2007, but dropped drastically in the following year (2008). As at the year 2008, so many companies were unable to recover from the shock, thereafter leading to various questions on the factors associated with the fall in the world capital market as well as the downturn in the trend of events in the world capital market. The share price index of all the selected countries, which represents the world capital market, had sharp increase in their share price in the year 2007, but was not sustained in the year 2008 when they all had a reduction in their share price index.

As at 2009, of all the selected countries, none was able to meet up with the share price index of the year 2006 except South Africa, showing that the fall did not just occur in 2008, but also in 2009. Nigeria also witnessed the same trend and has not been able to meet up with the 2007 performance of a share price index of 57990.22, as this was higher than the 2006 price index of 33189.30, which later decreased to 31450.78 in 2008, a level lower than the 2006 index. Also of note is the fact that instead of the capital market improving in its share price index, this declined further in the year 2009 to 20827.17, a level lower than the 2005 and the 2004 benchmark.

The nationalization/bailout of Platinum Habib Bank (Bank PHB) Nigeria Ltd, Afribank Nigeria Ltd and Spring Bank Nigeria Ltd by the apex bank in Nigeria (Central Bank of Nigeria) and the subsequent adoption of the bridge bank mechanism, Evans medical financial crisis, as well as the 2006 - 2008 Cadbury saga (Amao \& Amaeshi, 2008), which heralded the beginning of the financial crisis in Nigeria points to the fact that Nigerian companies are going through tough periods. The financial crisis, did not only concern corporations and banks but also affected investors who lost considerable amounts of money on investments (Ogunwusi \& Eazee, 2011; Anaro, 2011). Worthy of note also is the fact 
that most of the bridged banks as well as the liquidated ones found their names on the list of the most capitalized companies listed on the Nigerian Stock Exchange in the year 2008. On this list, Oceanic Bank International Plc was the sixth on the Table with N267.767 billion as the market capital, but taken over by Ecobank International Plc in 2012. Intercontinental Bank Nigeria PIc took the seventh position with N243.055 billion as its market capital in 2008, has also been taken over by Access Bank plc in 2012. Bank PHB Plc took the ninth position with a market capital of N206.387 billion, Wema Bank ranking as the sixteenth with a market capitalization of N145.562 billion and Afribank Nigeria Plc taking the eighteenth position, with market capital of N129.810 billion.

Turnover, business performance and the profitability of companies are expected to be some of the factors responsible for their level of capitalization, but this is not reflected in the aftermath performance of these companies in 2010 up till 2012. As at 2012, majority of the companies that were listed on the Nigerian Stock Exchange could not recover fully from the 2007/2008 shock, which affected their share price, with the share price of the companies falling and majority not been able to meet up with the 2007 benchmark in the year 2009, except for a few like Avon Crowncaps, Guinness Nig Ltd and Vitafoam.

The accounting scandals such as the Cadbury misstatement of reports as well as the Evans medical case shows that managers sometimes mislead stakeholders about the financial performance of their companies by publishing financial reports that do not provide a true representation of the company's value. Although these statements are asserted to portray the true and fair view of the audited companies (Ogunwusi \& Eazee, 2011; Anaro, 2011; Bello, 2011; Ighomwenghian, 2010; Murya, 2010; Chih-Fong \& Yen-Jiun, 2009; Okoye \& Alao, 2008). This however erodes the function of financial reporting. According to Amao \& Amaeshi (2008), there has been a call for public accountability which resulted in shareholders activitism in Nigeria, how effective has these been on the nation Nigeria?

With effect from 2008, a series of accounting manipulations in Nigeria such as reported in relation to Wema Bank, Intercontinental Bank, Oceanic Bank, Finbank, and Spring bank in Nigeria, has captured the attention of stakeholders such as investors and regulators alike, leaving many probing questions in the mind of stakeholders. Thus, why do we still have these problems, after the enactment of the code? Since the code of corporate governance has been said to be a good tool for the reduction of misappropriation of fund in Nigerian companies, is corporate governance the cause of this revelation? Has the enactment of the code reduced earnings management practices in Nigeria? What has been the effect of corporate governance on earnings management practices of companies in Nigeria?

The preparers of financial reports as professionals are bound by the code of ethics of their professional bodies, which is expected to enhance their level of integrity, which will ultimately enhance the level of reliability placed on the financial reports pulished by them. However the financial reports that have been tagged falsified in time past, can it then be said that they were not prepared by qualified accountants, what is the disposition of the preparers of financial rports to financial integrity?

This study is aimed at finding answers to some of the questions posited above; examine the earnings management practices in Nigeria and evaluate the role of corporate governance in checkmating the adverse effect of earnings management on publicly quoted companies in Nigeria. It seeks to examine the role of corporate governance in curbing earnings management practices in Nigeria, with a focus on sampled preparers of financial reports in Nigeria.

\section{Materials and Methods}

Earnings management is a topical issue that has been widely reviewed and evaluated from different perspectives and dimensions in accounting literature as well as documentaries. It has received great attention globally and its effect on the level of reliability placed on the financial reports of companies (Uadiale, 2012; Murya, 2010; Beaudoin, 2008; Bugshan, 2005). However there seems to be dearth of information on earnings management practices in Nigeria and the Nigerian firms (Bello, 2011; Okoye \& Alao, 2008), though different questions have been raised on the reasons for corporate failures in the Nigerian environment (Anaro, 2011) even when reported earnings look vibrant and portray that of a going concern (Ogunwusi \& Eazee, 2011).

Many preparers of financial reports have been accused of engaging in various forms of earnings management practices, in a bid to either secure their job by giving the users of the reports what they want to see and not necessarily report the situation in the company (Bello, 2011; Chih-Fong \& Yen-Jiun, 2009), which is as a result of the divergent interest of the various users of the accounting information and the resultant effect of which is the reduction in the value placed on financial reports by the users of the report (Okoye \& Alao, 2008). In an attempt to reduce this trend, the code of corporate governance was published in 2003 in Nigeria, by the Security and Exchange Commission (SEC) in conjunction with the Nigerian Corporate Affairs Commission (CAC), the document which is believed to bridge the gap between the information need of the various users of the financial reports. The code looked at the ways by which companies could be 
managed in such a way that the interest of the various stakeholders in the company is considered in the management of the company, the preparation of the reports as well as the presentation of the reports for the various users (SEC, 2003).

In developed countries, research has shown that corporate governance reduces the earnings management practices carried out in companies, giving greater credence to the financial reports of companies, however, the opposite happens to be the case in Nigeria, where the code was published in 2003 and quoted companies have been mandated to adhere to the contents of the code. A close look at the Nigerian business environment shows that from 2003 till date there has been several cases of company fold up and financial scandals in Nigeria (Anaro, 2011; Ogunwusi \& Eazee, 2011; Ighomwenghian, 2010; Microfinance Africa, 2010; Onwuamaeze, 2008). This however poses a question on the effectiveness of the code of corporate governance in Nigeria and its effect on earnings management practice. Is corporate governance a variable responsible for the discovery of the various scandals, and has it improved financial reporting integrity, what is the extent of compliance to the code of coporate governance in Nigeria?

Different methods have been used by past researchers to analyse the data gathered in relation to the subject matter. Fodio, Ibikunle \& Oba (2013) used the cross-sectional variation of the modified Jones model to measure discretionary accruals, which is a proxy for earnings quality/earnings management when they examined the effect of corporate governance mechanisms on earnings management practices of sampled Insurance companies in Nigeria, Uadiale (2012) sampled the opinion of 80 Nigerian respondents, using t-test to examine the effect of corporate governance mechanisms on earnings management practices in Nigeria, Bello (2011) with 90 firm year observation, using the probit method of analysis examined the effect of corporate governance mechanisms on earnings management practices in Nigeria, while Chtourou, Bedard, \& Courteau (2001) using 300 US based firms adopted the Logistic Regression method of analysis to evaluate the effect of corporate governance on earnings management practices in the United State of America. Shen \& Chih (2007) evaluating the effect of corporate governance mechanisms on earnings smoothing of 495 sampled companies adopted the use of multiple regression, while Murya (2010) evaluating the effect of corporate governance on earnings management of 350 companies listed on the London Stock Exchange used the Ordinary Least Square Regression technique. Based on the nature of the study at hand and the data set available, this study will be using the OLS regression method to analyse the primary data

This study therefore sets out to evaluate the research hypothesis stated in null form below:

$\mathrm{H}_{0}$ : Corporate Governance does not have a significant effect on Earnings Management Practices in Nigeria, as identified by the preparers of financial reports

\section{Methodology}

A total of 400 copies of the research questionnaire was administered, 387 copies were recovered but 354 copies of the research questionnaire were found useful for analyses and evaluation.

The research questionnaire was designed to cover every aspect of the research objective and the research hypothesis. The items of the research questionnaire were structured to contain statements from which respondents were expected to state the extent to which they agree to the statements. The questionnaire was structured in a 5 to 1 Likert scale form, whereby respondents' perceptions about some statements are weighed appropriately.

The data gathered from the administered research questionnaire was analysed using the ordinary least squares (OLS) regression and Correlation Coefficient. This was used to determine the type of relationship that exists between two variables (corporate governance and earnings management), and the opinion of financial report preparers on the effect of corporate governance on earnings management.

The model for the hypothesis is as written below:

$\mathrm{EEM}=\mathrm{f}(\mathrm{COPG})$.............................. Equation (1)

Where

EEM: Earnings management

COPG: Corporate governance

\section{Results}

The tables below give a summary of the result of the tested research hypothesis. 
Model Summary

\begin{tabular}{|c|c|c|c|c|}
\hline Model & $\mathrm{R}$ & R Square & Adjusted R Square & Std. Error of the Estimate \\
\hline 1 & $.575(\mathrm{a})$ & .331 & .320 & .41624 \\
\hline
\end{tabular}

a Predictors: (Constant), Audqual, audcomp, corpcod, Duality, bodmeet, bodcomp

This model shows how much of variance in the dependent variable (earnings management) is explained by the independent variables (Audit committee qualification, Audit committee composition, Enforcement of Code of Corporate Governance, Dualisation of chairman and ceo position, Frequency of board meetings and Board composition). For this model, $\mathrm{R}$ square is 0.331 , which means $33.1 \%$ of the variance in the independent variable explains the behaviour of the dependent variable.

ANOVA(b)

\begin{tabular}{|cc|c|c|c|c|c|}
\hline Model & & Sum of Squares & Df & Mean Square & F & Sig. \\
\hline 1 & Regression & 29.769 & 6 & 4.962 & 28.638 & $.000(\mathrm{a})$ \\
& Residual & 60.119 & 347 & .173 & & \\
& Total & 89.888 & 353 & & & \\
\hline
\end{tabular}

a Predictors: (Constant), Audqual, audcomp, corpcod, Duality, bodmeet, bodcomp

b Dependent Variable: Earnmgt

This examines the null hypothesis to determine if the null hypothesis should be rejected or not. This model is statistically significant (significance of 0.0000 ) at $1 \%$ significant level; hence the null hypothesis is rejected and the alternate hypothesis accepted. It therefore connotes that preparers of financial reports in Nigeria see corporate governance as a tool for curbing earnings management practices in Nigeria.

Coefficients(a)

\begin{tabular}{|cc|c|c|c|c|c|}
\hline \multicolumn{2}{|l|}{ Model } & \multicolumn{2}{|c|}{ Unstandardized Coefficients } & Standardized Coefficients & $\mathrm{t}$ & Sig. \\
\hline & & $\mathrm{B}$ & Std. Error & Beta & $\mathrm{B}$ & Std. Error \\
\hline 1 & (Constant) & 1.618 & .184 & & 8.807 & .000 \\
& Corpcod & .137 & .039 & .192 & 3.481 & .001 \\
& Bodcomp & -.100 & .068 & -.103 & -1.467 & .143 \\
& Duality & .268 & .062 & .295 & 4.323 & .000 \\
& Bodmeet & .162 & .060 & .180 & 2.712 & .007 \\
& Audcomp & .103 & .046 & .121 & 2.239 & .026 \\
& Audqual & .013 & .052 & .016 & .251 & .802 \\
\hline
\end{tabular}

a Dependent Variable: Earnmgt

From the t-statistics value above (enforcement of code of corporate governance has a t-value of 3.481 and a $p$-value of 0.001 ) the p-value of corporate governance is significant at $1 \%$ significant level. Therefore the null hypothesis is rejected and the alternate hypothesis accepted. The construct board composition is insignificant, as well as the construct audit committee qualification. Audit committee composition, frequency of board meetings as well as duality of chairman and ceo position are also significant alongside the enforcement of code of corporate governance.

\section{Discussion}

The study therefore shows that the preparers of financial reports in Nigeria see corporate governance as a tool for reducing earnings management practices in Nigeria. This study however revealed that there is a significant relationship between corporate governance and earnings management practices in Nigeria, as identified by the preparers of the financial reports. Since earnings management practice as well as corporate governance are behavioural issues, thus the preparers of financial reports are of the opinion that the higher the enforcement of the contents of the code of corporate governance, the lower will be the earnings management practices of companies in Nigeria.

Decision: From the analyses and interpretations above, it is clear that the preparers of financial reports in Nigeria have a positive perception towards corporate governance in deterring earnings management practices in Nigeria. To this end, the null hypothesis is rejected and the alternate hypothesis accepted to conclude that the preparers of financial reports in Nigeria see corporate governance as a tool for curbing earnings management practices in Nigeria 
Table 1. Summary of Reliability and Validity Checks

\begin{tabular}{|c|c|}
\hline Test & Result \\
\hline Cronbach's Alpha & 0.864 \\
\hline Cronbach's Alpha Standardized Items & 0.883 \\
\hline Lambda & $\begin{array}{r}1: 0.756 \\
2: 0.868 \\
3: 0.864 \\
4: 0.887 \\
5: 0.851 \\
6: 0.874\end{array}$ \\
\hline Test of Goodness of Fit & $\begin{array}{l}\text { Chi-Square - Value } 734.003 \\
\text { Df } \quad 34 \\
\text { Sig } \quad 0.000 \\
\text { Log of Determinant - Unconstrained Matrix: }-11.530 \\
\text { Constrained Matrix: } \quad-9.433\end{array}$ \\
\hline Parallel Model & $\begin{array}{|lc|}\text { Common Variance } & -0.429 \\
\text { True Variance } & -0.190 \\
\text { Error Variance } & -0.240 \\
\text { Common Inter-tem Correlation } & -0.442 \\
\text { Reliability of Scale } & -0.864 \\
\text { Reliability of Scale (Unbiased) } & -0.864 \\
\end{array}$ \\
\hline Cases & $\begin{array}{l}\text { Valid } 354 \\
\text { Excluded } 0 \\
\text { Total } \quad 354\end{array}$ \\
\hline $\mathrm{N}$ & 8 \\
\hline
\end{tabular}

Source: Field Study

\section{Test of Correlation}

Below is the test of correlations between the variables measured.

Table 2: Correlations of Variable

\begin{tabular}{|c|c|c|c|c|c|c|c|c|}
\hline & & corpcod & Earnmgt & bodcomp & Duality & bodmeet & audcomp & Audqual \\
\hline Corpcod & $\begin{array}{l}\text { Pearson Correlation } \\
\text { Sig. (2-tailed) }\end{array}$ & 1 & & & & & & \\
\hline Earnmgt & $\begin{array}{l}\mathrm{N} \\
\text { Pearson Correlation } \\
\text { Sig. (2-tailed) } \\
\text { N }\end{array}$ & $\begin{array}{c}354 \\
.429\left(^{* *}\right) \\
.000 \\
354\end{array}$ & 354 & & & & & \\
\hline Bodcomp & $\begin{array}{l}\text { Pearson Correlation } \\
\text { Sig. (2-tailed) } \\
\mathrm{N}\end{array}$ & $\begin{array}{l}.538\left(^{* *}\right) \\
.000 \\
354\end{array}$ & $\begin{array}{l}\left..382{ }^{* *}\right) \\
.000 \\
354\end{array}$ & 354 & & & & \\
\hline Duality & $\begin{array}{l}\text { Pearson Correlation } \\
\text { Sig. (2-tailed) } \\
\text { N }\end{array}$ & $\begin{array}{c}.502\left(^{* *}\right) \\
.000 \\
354\end{array}$ & $\begin{array}{l}.501\left(^{* *}\right) \\
.000 \\
354\end{array}$ & $\begin{array}{l}.709\left(^{(* *}\right) \\
.000 \\
354\end{array}$ & $\begin{array}{c}1 \\
354\end{array}$ & & & \\
\hline Bodmeet & $\begin{array}{l}\text { Pearson Correlation } \\
\text { Sig. (2-tailed) } \\
\text { N }\end{array}$ & $\begin{array}{c}.509\left(^{* *}\right) \\
.000 \\
354\end{array}$ & $\begin{array}{c}.475\left(^{(* *}\right) \\
.000 \\
354\end{array}$ & $\begin{array}{c}.608\left(^{* *}\right) \\
.000 \\
354\end{array}$ & $\begin{array}{l}.626\left({ }^{* *}\right) \\
.000 \\
354\end{array}$ & $\begin{array}{c}1 \\
354\end{array}$ & & \\
\hline Audcomp & $\begin{array}{l}\text { Pearson Correlation } \\
\text { Sig. (2-tailed) } \\
N\end{array}$ & $\begin{array}{l}\left..3699^{* \star}\right) \\
.000 \\
354\end{array}$ & $\begin{array}{c}.398\left(^{* \star}\right) \\
.000 \\
354\end{array}$ & $\begin{array}{c}\left..4322^{* *}\right) \\
.000 \\
354\end{array}$ & $\begin{array}{l}\left..501{ }^{* *}\right) \\
.000 \\
354\end{array}$ & $\begin{array}{c}.526\left(^{* *}\right) \\
.000 \\
354\end{array}$ & $\begin{array}{c}1 \\
354\end{array}$ & \\
\hline Audqual & $\begin{array}{l}\text { Pearson Correlation } \\
\text { Sig. (2-tailed) } \\
\text { N }\end{array}$ & $\begin{array}{c}.500\left(^{* *}\right) \\
.000 \\
354\end{array}$ & $\begin{array}{c}.390\left(^{(*}\right) \\
.000 \\
354\end{array}$ & $\begin{array}{l}.638\left(^{* *}\right) \\
.000 \\
354\end{array}$ & $\begin{array}{l}\left..564{ }^{* *}\right) \\
.000 \\
354\end{array}$ & $\begin{array}{c}.653\left(^{* \star}\right) \\
.000 \\
354\end{array}$ & $\begin{array}{c}.486\left(^{* *}\right) \\
.000 \\
354\end{array}$ & $\begin{array}{c}1 \\
354\end{array}$ \\
\hline
\end{tabular}

** Correlation is significant at the 0.01 level (2-tailed).

Source: Field Study 


\section{References}

Accounting Aisle. (2011). Financial Statements - Why they're a Good Idea . Retrieved September 1, 2011, from Accounting Aisle: http://www.accountingaisle.com/knowledge/financial-statements.php

Adegbite, E. (2012). Corporate governance in the Nigerian banking industry: towards governmental engagement. International Journal of Business Governance and Ethics. 7 (3), 209-231.

Adegbite, E. (2012). Corporate governance regulation in Nigeria. Corporate Governance., 12 (2), 257-276.

Akintoye, I.R. (2008). Efficient market hypothesis and behavioural finance: A review of literature. European Journal of Social Sciences. 7 (2), $7-17$.

Amao, O., \& Amaeshi, K. (2008). Galvanising shareholder activism: A prerequisite for effective corporate governance and accountability in Nigeria. Journal of Business Ethics. 82 (1), 119-130.

Amernic, J., \& Craig, R. (2009). Understanding accounting through conceptual metaphor: Accounting is an Instrument? Critical Perspectives on Accounting , 875-883.

Anaro, B. (2011, August 22). Winners, losers from the debris of banking consolidation. Business Day.

Appalachian, S. U. (2006, October 27). Theories Used in IS Research: Stakeholder Theory. Retrieved September 1, 2011, from York University: http://www.istheory.yorku.ca/stakeholdertheory.htm.

Beaudoin, C. A. (2008). Earnings management: The role of the agency problem and corporate social responsibility. Drexel University.

Bello, A. (2011). Corporate governance and accounting ethics in Nigeria. International Conference on Management (ICM 2011) Proceeding. (pp. 1591-1608).

Bugshan, T. (2005). Corporate governance, earnings management, and the information content of accounting earnings: Theoretical model and empirical tests. Queensland: Bond University.

Chih-Fong, T., \& Yen-Jiun, C. (2009). Earnings management prediction: A pilot study of combining neural networks and decision trees. Expert Systems with Applications $36,7183-7191$.

Deakin, S., \& Suzanne, J. K. (2004). Learning from enron. Corporate Governance: An International Review. 12 (2), 134-142.

Fodio, M. I., Ibikunle, J., \& Oba, V. C. (2013). Corporate governance mechanisms and reported earnings quality in listed Nigerian insurance firms. International Journal of Finance and Accounting , 279-286.

Freeman, R. E., Wicks, A. C., \& Parmar, B. (2004). Stakeholder theory and the corporate objective revisited. Organization Science. 364369.

Hand, J. R. (2004). The Value Relevance of Financial Statements in Private Equity Markets. Available at SSRN: http://ssrn.com/ abstract $=484382$.

Ighomwenghian, K. (2010, April 13). Evans medicals - Making of another cadbury-gate? Daily Independence .

Ireland, J. (2005). Principles of Accounting. England: Central Printing Service, University of London.

Joseph, K., \& Atul, R. (2007). Intra-year shifts in the earnings distribution and their implications for earnings management. Journal of Accounting and Economics. 44, 399-419.

Koornhof, C. (1998). Accounting and accounting information. Pretoria: University of Pretoria.ed

Kothari, S., Ramanna, K., \& Skinner, D. J. (2010). Implications for GAAP from an analysis of positive researchinaccounting. Journal of Accounting and Economics, 246-286.

Liming, G., Charlotte, J. W., \& Shannon, L. L. (2005). Earnings Management and Forced CEO Dismissal. Advances in Accounting 21 , 61-81.

Microfinance Africa. (2010, July 27). Former Chartered Institute of Bankers of Nigeria boss urges consistency in financial regulation policies. Nigerian Compass. Retrieved November 15, 2013, from. http://microfinanceafrica.net/tag/increase-in-nigerianmicrofinance-capital-base/.

Murya, H. (2010). The Effectiveness of Corporate Governance and External Audit on Constraining Earnings Management Practice in the UK. Durham: Durham University.

Ogunwusi, B., \& Eazee, L. (2011, July 14). Investor Loss N149.047 Billion in Three Days. Daily Independent .

Ojeka S. A., Iyoha F.O., and Obigbemi I.F. (2013). Audit committee characteristics and firm financial performance in Nigeria: An empirical analysis. Journal of Accounting and Auditing: Research \& Practice.

Okoye, I. E., \& Alao, B. (2008). The Ethics of Creative Accounting in Financial Reporting: The Challenges of Regulatory Agencies in Nigeria. The Certified National Accountant 16 (1) , 45-55.

Onwuamaeze, D. (2008, April 20). Cadbury's Fraudulent Directors Punished. News Watch .

Otusanya, J. O., \& Lauwo, S. (2010). The Role of Auditors in the Nigerian Banking Crisis. Accountancy Business and the Public Interest, Vol. $9,159-204$.

Ramly, Z., \& Rashid, H. M. (2010). Critical review of literature on corporate governance and the cost of capital: The value creation perspective. African Journal of Business Management 4(11) , 2198-2204.

Revsine, L. (1969). General Purpose Reports and Users' Data Needs. Financial Analysts Journal , 37-46.

Samaha, K., Dahawy, K., Hussainey, K., \& Stapleton, P. (2012). The extent of corporate governance disclosure and its determinants in a developing market: The case of Egypt. Advances in Accounting, incorporating Advances in International Accounting 28 , 168178.

Security \& Exchange Commission. (2003). Code of Corporate Governance in Nigeria. Lagos: Corporate Affairs Commission.

Security and Exchange Commission. (2010). Nigerian Capital Market Statistical Bulletin. Garki, Abuja: Office of the Chief Economist and 
Research Division of the Research and Planning Department, Securities and Exchange Commision.

Shen, C., \& Chih, H. (2007). Earnings management and corporate governance in Asia's emerging markets. Corporate Governance: An International Review 15 (5).

Sori, Z. M. (2009). Accounting Information Systems (AIS) and Knowledge Management: A Case Study. American Journal of Scientific Research, 36-44.

Stanford, G. (2005, November). Financial Statements Are Still Valuable Tools for Predicting Bankruptcy. Retrieved September 1, 2011, from Stanford Graduate School of Business: http://www.gsb.stanford.edu/news/research/acctg_mcnichols-beaver_bankruptcy. shtml

Uadiale, O. M. (2012). Earnings management and corporate governance in Nigeria. Research Journal of Finance and Accounting .

Universal College of Accountancy. (2004). Study Pack on Basic Accounting for ATS 1. Lagos: Philglad Nigeria Limited. 